\title{
DIFFERENT PERIPHERAL SUBSTITUTED PHTHALOCYANINES: SYNTHESIS, CHARACTERIZATION, AGGREGATION BEHAVIOR, ANTIOXIDANT AND ANTIBACTERIAL ACTIVITY
}

\author{
M. Çelebi ${ }^{1}$, M.S. Ağirtaş ${ }^{1}$, A. Dundar ${ }^{2}$ \\ ${ }^{1}$ Department of Chemistry, Faculty of Science, Yüzüncü Yll University, 65080, Van, Turkey \\ E-mail: salihagirtas@hotmail.com \\ ${ }^{2}$ Vocational Higher School of Health Services Medical Promotion and Marketing Program, Mardin Artuklu \\ University, 47000, Mardin, Turkey
}

Received May, 27, 2014

\begin{abstract}
In this study, a novel phthalonitrile, 4-chloro-5-(2-((2-hydroxyethyl)( $p$-tolyl)amino)ethoxy)phthalonitrile (3), and its metallophthalocyanine derivatives (4-6) are prepared by cyclotetramerization with appropriate metal salts in dimethylformamide. The newly prepared compounds have been characterized by several spectroscopic techniques. All compounds are evaluated for their antioxidant and antibacterial potential. For the antioxidant studies, three tests are applied; DPPH (2,2-diphenyl-1-picrylhydrazylradical) scavenging, metal chelating and reducing power activity. Compound $\mathbf{4}$ exhibits the best DPPH scavenging activity as $35.2 \%$ at $100 \mathrm{mg} / \mathrm{L}$ concentration. The metal chelating activities of compounds $\mathbf{3}$ and $\mathbf{4}$ are $69.7 \%$ and $56.4 \%$, respectively. Reducing power activities of compounds 3 and $\mathbf{4}$ are higher than $\alpha$-tocopherol which is used as positive control. All compounds show moderate antibacterial activity when compared to the standard antibiotics, amikacin and tetracycline.
\end{abstract}

DOI: $10.15372 /$ JSC20150828

K e y w o r d s: synthesis, metal, phthalocyanines, aggregation, antioxidant, antibacterial activity.

\section{INTRODUCTION}

The synthesis of the peripherally substituted phthalocyanines has attracted considerable attention due to their electronic properties and chemical structure [1,2]. The unique properties of phthalocyanines have encouraged researchers to synthesize new derivatives with certain properties required for applications such as therapeutic medicine, photodynamic therapy, materials science, catalytic therapy and antioxidant potentials [ $3-5$ ]. For this purpose, many applications of phthalocyanines in different fields, including dyes and pigments [6], semiconductors [7], optical data storage [8], photosensitizers [9], liquid crystals [10], nonlinear optics [11], gas sensors [12], catalysis [13] and Langmuir-Blodgett films [14] have been found. However, there are some notable drawbacks for the use of phthalocyanines, like poor solubility in a wide range of solvents and the aggregation tendency to form aggregates in solution [15]. To overcome these drawbacks, starting materials with suitable substituents must be chosen to synthesize new phthalocyanine derivatives. For this purpose, 2,2'-(4methylphenylimino)diethanol can be chosen as a starting material since it is soluble in organic solvents and does not have a tendency to form aggregates. It has a good potential to evaluate the antioxidant and antibacterial activities. The most current research on antioxidant action focuses on phenolic compounds and phthalocyanine derivatives. The antioxidants are show the functions as singlet-triplet oxygen quencher, free radical scavengers, peroxide decomposers, enzyme inhibitors and synergists

(C) Çelebi M., Ağirtaş M.S., Dundar A., 2015 
$[16,17]$. It is believed that antioxidants play a very important role in the body defense system against reactive oxygen species.

In this study, we describe the synthesis and characterization of phthalocyanines bearing tetra 4-chloro-5-(2-((2-hydroxyethyl)(p-tolyl)amino)ethoxy) substituents in the peripheral positions. We also report the results of a comprehensive investigation of the concentration effects on the aggregation properties of phthalocyanine derivatives in THF. Additionally, the antioxidant and antimicrobial activities of the phthalocyanines have been investigated by using antioxidant assays and disc diffusion method.

\section{EXPERIMENTAL}

General. The starting material, 4,5-dichlorophthalonitrile, was synthesized by the literature method [ 18 ]. Other chemicals were purchased from Sigma, Aldrich etc. and used without purification. The solvents were purified according to the standard procedures [19] and stored over molecular sieves $(4 \AA)$. All reactions were carried out under dry nitrogen. The purity of the novel products was tested in each step by thin layer chromatography. Melting points were measured on an electrothermal apparatus. Electronic spectra were recorded on a Hitachi U-2900 Spectrophotometer (Van YYU, Central Laboratory, Turkey). Routine IR spectra were recorded on a Thermo Scientific FTIR (ATR sampling accessory) spectrophotometer (Van YYU, Central Laboratory, Turkey). Mass spectra were recorded on an AB Sciex 3200 Q Trap LC-MS/MS spectrometry and MALDI (matrix assisted laser desorption ionization) BRUKER Microflex LT using 2,5-dihydroxybenzoic acid as matrix. ${ }^{1} \mathrm{H}$ NMR spectra were recorded on a Bruker $300 \mathrm{MHz}$ spectrometer (Malatya IBTAM, Central Laboratory, Turkey).

4-Chloro-5-(2-((2-hydroxyethyl)(p-tolyl)amino)ethoxy)phthalonitrile (3). A mixture of 2,2'(4-methylphenylimino)diethanol $2(0.976 \mathrm{~g}, 5 \mathrm{mmol})$ and 4,5-dichlorophthalonitrile 1 (0.985 g, $5 \mathrm{mmol}$ ) in $25 \mathrm{~mL}$ dimethylformamide (DMF) was stirred at room temperature under nitrogen atmosphere. After stirring for $15 \mathrm{~min}, \mathrm{~K}_{2} \mathrm{CO}_{3}(2.5 \mathrm{~g}, 18 \mathrm{mmol})$ was added into the mixture over a period of $2 \mathrm{~h}$. After stirring for a further $24 \mathrm{~h}$, the reaction mixture was poured into water $(200 \mathrm{~mL})$ and extracted with $\mathrm{CH}_{2} \mathrm{Cl}_{2}$. The crude product was washed first with $10 \% \mathrm{NaHCO}_{3}$ and then with water and dried over anhydrous sodium sulfate. The solution was evaporated to dryness. The product is soluble in THF, ethanol, acetonitrile, acetone, ethyl acetate, $\mathrm{CH}_{2} \mathrm{Cl}_{2}, \mathrm{CHCl}_{3}, \mathrm{DMF}$ and DMSO. Yield: $1.128 \mathrm{~g}$ (64 \%). MP: $117^{\circ} \mathrm{C} .{ }^{1} \mathrm{H}$ NMR (300 MHz, DMSO- $\left.d_{6}\right) \delta$, ppm: $8.34-6.67(\mathrm{Ar}-\mathrm{H}), 3.54(\mathrm{OH}), 4.38-$ 3.78 (aliphatic groups), $2.50\left(\mathrm{CH}_{3}\right)$. IR spectrum $\left(\mathrm{cm}^{-1}\right): 3276(\mathrm{OH}), 3085-3015(\mathrm{Ar}-\mathrm{CH}), 2923$ $\left(\mathrm{CH}_{3}\right), 2238(\mathrm{CN}), 1617,1575,1257,1221,1142,1044,914,802,683$ and 529. Anal. Calc. for $\mathrm{C}_{19} \mathrm{H}_{18} \mathrm{ClN}_{3} \mathrm{O}_{2}$ (\%): $\mathrm{C}$ 64.13, H 5.10, N 11.81. Found (\%): C 64.21; H 5.18; N 11.74. MS (ES), $m / z=355[\mathrm{M}]^{+}$.

Synthesis of zinc(II) phthalocyanine (4). A mixture of 4-chloro-5-(2-((2-hydroxyethyl)( $p$ tolyl)amino)ethoxy)phthalonitrile $3(0.142 \mathrm{~g}, 0.40 \mathrm{mmol})$ and $\mathrm{ZnCl}_{2}(0.020 \mathrm{~g})$ were dissolved in dimethylformamide $(2 \mathrm{~mL})$ under nitrogen in the presence of DBU. The mixture was refluxed under stirring for $24 \mathrm{~h}$. After cooled down the crude product was precipitated by adding water. The precipitate was filtered, washed with cold and hot ethanol, methanol several times. Then, it was extracted with THF and dried. It was then purified by column chromatography on silicagel with THF as eluent. The product is soluble in $\mathrm{CHCl}_{3}, \mathrm{CH}_{2} \mathrm{Cl}_{2}$, THF, DMF and DMSO. The yield was $0.055 \mathrm{~g}(37 \%)$. ${ }^{1} \mathrm{H} \mathrm{NMR}$ $\left(\mathrm{DMSO}-d_{6}\right) \delta$, ppm: $8.98-6.64(\mathrm{Ar}-\mathrm{H}), 3.47(\mathrm{OH}), 4.83-3.85$ (aliphatic groups), 2.50-2.19 $\left(\mathrm{CH}_{3}\right)$. UV-Vis (THF) $\lambda_{\max }(\log \varepsilon): 670(4.73), 612(4.38), 346(4.66)$. IR spectrum $\left(\mathrm{cm}^{-1}\right): 3328(\mathrm{OH})$, $3062(\mathrm{Ar}-\mathrm{CH}), 2910-2848\left(\mathrm{CH}_{3}\right), 1601,1517,1257,1181,1085,1042,882,741,655$ and 507. Calc. for $\mathrm{C}_{76} \mathrm{H}_{72} \mathrm{Cl}_{4} \mathrm{~N}_{12} \mathrm{O}_{8} \mathrm{Zn}(\%)$ : C 61.32, H 4.87, N 11.29. Found (\%): C 61.39, H 4.79, N 11.22. MS: $m / z 1488[\mathrm{M}]^{+}$.

Synthesis of cobalt(II) phthalocyanine (5). The procedure is similar to the synthesis of $\mathbf{4}$ from $\mathbf{3}$, except using $\mathrm{CoCl}_{2}$. The product is soluble in DMF, THF, $\mathrm{CHCl}_{3}, \mathrm{CH}_{2} \mathrm{Cl}_{2}$ and DMSO. The yield was $0.065 \mathrm{~g}(44 \%)$. UV-Vis (THF) $\lambda_{\max }(\log \varepsilon): 660$ (4.71), 320 (4.69). IR spectrum $\left(\mathrm{cm}^{-1}\right): 3330(\mathrm{OH})$, $3073(\mathrm{Ar}-\mathrm{CH}), 2921-2859\left(\mathrm{CH}_{3}\right), 1605,1518,1257,1227,1088,1044,830,1797,747$, and 503. Calc. for $\mathrm{C}_{76} \mathrm{H}_{72} \mathrm{Cl}_{4} \mathrm{~N}_{12} \mathrm{O}_{8} \mathrm{Co}(\%)$ : C 61.58, H 4.90, N 11.34. Found (\%): C 61.54, H 4.96, N 11.42. MS: $m / z 1482.2[\mathrm{M}]^{+}$. 
Synthesis of copper(II) phthalocyanine (6). The procedure is similar to the synthesis of $\mathbf{4}$ from 3, except using $\mathrm{CuCl}_{2}$. The product is soluble in $\mathrm{CH}_{2} \mathrm{Cl}_{2}, \mathrm{CHCl}_{3}, \mathrm{DMF}$, THF and DMSO. The yield was $0.040 \mathrm{~g}(27 \%)$. UV-Vis (THF) $\lambda_{\max }(\log \varepsilon): 676$ (4.69), 616 (4.38), 340 (4.60). IR spectrum $\left(\mathrm{cm}^{-1}\right)$ : $3330(\mathrm{OH}), 3067(\mathrm{Ar}-\mathrm{CH}), 2919-2853\left(\mathrm{CH}_{3}\right), 1605,1534,1261,1232,1071,1048,799,742,717$, and 521. Calc. for $\mathrm{C}_{76} \mathrm{H}_{72} \mathrm{Cl}_{4} \mathrm{~N}_{12} \mathrm{O}_{8} \mathrm{Cu}(\%)$ : $\mathrm{C}$ 61.39, $\mathrm{H}$ 4.88, $\mathrm{N}$ 11.30. Found (\%): $\mathrm{C} 61.48, \mathrm{H} 4.77$, N 11.21.

DPPH scavenging activity. DPPH scavenging activity of the compound 3 and its phthalocyanine complexes was determined spectrophotometrically by measuring the change in the absorbance of free radical (2,2-diphenyl-2-picrylhydrazyl) at $517 \mathrm{~nm}$ [20]. $0.5 \mathrm{~mL}$ DMF solutions of complexes were diluted with DMF to obtain solutions with different concentrations $(5 \mathrm{ppm}, 10 \mathrm{ppm}, 25 \mathrm{ppm}, 50 \mathrm{ppm}$, and $100 \mathrm{ppm}$ ). These samples were added to $2 \mathrm{~mL}$ of methanol solution of DPPH. The final mixtures were shaken vigorously and incubated in the dark for $60 \mathrm{~min}$ in an incubator at $25^{\circ} \mathrm{C}$. Absorbance values at $517 \mathrm{~nm}$ were measured using DMF solution as a blank control. Ascorbic acid and trolox were used as positive control. The scavenging effect was calculated using the following formula:

$$
\text { scavenging activity }(\%)=\left(A_{\mathrm{c}}-A_{\mathrm{s}}\right) \div A_{\mathrm{c}} \times 100 \text {, }
$$

where $A_{\mathrm{c}}$ is the absorbance of the control and $A_{\mathrm{s}}$ is the absorbance of the sample. The data for antioxidant activities were presented as mean $\pm \mathrm{SD}$ of three determinations.

Metal chelating activity. The study of the metal chelating effects of compound $\mathbf{3}$ and its phthalocyanine complexes on ferrous ions was carried out as described in the literature [21 ]. One milliliter of DMF solution of the compound at different concentrations and $0.1 \mathrm{~mL} 2 \mathrm{mM} \mathrm{FeCl} \cdot \mathrm{H}_{2} \mathrm{O}, 0.2 \mathrm{~mL}$ $5 \mathrm{mM}$ ferrozine-1,2,4-triazine and $3.7 \mathrm{~mL}$ methanol were mixed in a test tube and allowed to react for $10 \mathrm{~min}$. The absorbance of reactants was measured at $562 \mathrm{~nm}$. The same mixture without compound was used as control. The minimum absorbance indicates the highest ferrous ion chelating capacity and is checked against EDTA as a positive control using formula given below:

$$
\text { metal chelating effect: }\left(A_{\mathrm{c}}-A_{\mathrm{s}}\right) / A_{\mathrm{c}} \times 100 \text {. }
$$

Reducing power. The compound 3 and its phthalocyanine complexes $(5-100 \mathrm{mg} / \mathrm{L})$ in $1 \mathrm{~mL}$ of distilled water were mixed with $2.5 \mathrm{~mL}$ of phosphate buffer $(0.2 \mathrm{M}, \mathrm{pH} 6.6)$ and $2.5 \mathrm{~mL}$ potassium ferricyanide $\left[\mathrm{K}_{3} \mathrm{Fe}(\mathrm{CN})_{6}\right](1 \%)$, and then the mixture was incubated at $50{ }^{\circ} \mathrm{C}$ for $30 \mathrm{~min}$. Afterwards, $2.5 \mathrm{~mL}$ of trichloroacetic acid $(10 \%)$ was added to the mixture, which was then centrifuged at $3000 \mathrm{rpm}$ for $10 \mathrm{~min}$. Finally, $2.5 \mathrm{~mL}$ of upper layer of the solution was mixed with $2.5 \mathrm{~mL}$ distilled water and $0.5 \mathrm{~mL} \mathrm{FeCl} 3(0.1 \%)$, and the absorbance was measured at $700 \mathrm{~nm}$ [22 ]. $\alpha$-Tocopherol was used as a positive control.

Antibacterial analyses. To determine the antimicrobial potential of the compound $\mathbf{3}$ and its phthalocyanine complexes, disc diffusion method was applied as described in the literature [23]. Escherichia coli (ATCC 10536), Staphylococcus aureus (ATCC 6538), Bacillus subtilis (6051), Enterococcus hirae (ATCC 10541), Micrococcus luteus (ATCC 9341), and Pseudomonas aeruginosa (ATCC 9027) were used as the test microorganisms. Nutrient broth (NB) was used for culturing of test bacteria. All strains were regenerated twice before use in the antimicrobial test.

\section{RESULTS AND DISCUSSION}

Synthesis and characterization. Phthalonitrile derivative 3 was obtained through the reaction of 2,2'-(4-methylphenylimino)diethanol $\mathbf{2}$ and 4,5-dichlorophthalonitrile $\mathbf{1}$ in dry DMF in the presence of dry $\mathrm{K}_{2} \mathrm{CO}_{3}$. The phthalocyanine complexes $\mathbf{4}-\mathbf{6}$ were obtained by heating the phthalonitrile 3 with $\mathrm{ZnCl}_{2}, \mathrm{CoCl}_{2}, \mathrm{CuCl}_{2}$ metal salts under $\mathrm{N}_{2}$ atmosphere. Scheme 1 shows the synthetic pathways for the compounds 3-6 used in this study. The characterization of the compounds was carried out by the combination of several methods, including elemental analysis, FT-IR, ${ }^{1} \mathrm{H}$ NMR, Mass spectrometry, and UV-Vis spectra.

The mass spectra of $\mathbf{3}-\mathbf{5}$ confirmed the proposed structure exhibiting the expected peaks at $m / z=355[\mathrm{M}]^{+}, m / z=1488[\mathrm{M}]^{+}$, and $m / z=1482.2[\mathrm{M}]^{+}$, respectively. The ${ }^{1} \mathrm{H}$ NMR spectrum of compound $\mathbf{3}$ was also in a good agreement with the structure of $\mathbf{3}$. The ${ }^{1} \mathrm{H}$ NMR spectrum of $\mathbf{3}$ showed 
aromatic ring protons between $8.34 \mathrm{ppm}$ and $6.67 \mathrm{ppm}$ as multiple peaks, $\mathrm{OH}$ proton at $3.45 \mathrm{ppm}$, aliphatic group protons at $4.38-3.78 \mathrm{ppm}$, and $\mathrm{CH}_{3}$ protons at $2.50 \mathrm{ppm}$. The ${ }^{1} \mathrm{H}$ NMR spectrum of 4 exhibits the characteristic signals of aromatic protons at $8.98-6.64 \mathrm{ppm}, \mathrm{OH}$ proton at $3.47 \mathrm{ppm}$, aliphatic groups at $4.83-3.85 \mathrm{ppm}$, and $\mathrm{CH}_{3}$ at $2.50-2.19 \mathrm{ppm}$.<smiles>Cc1ccc(N(CCO)CCOc2cc(C#N)c(C#N)cc2Cl)cc1</smiles>

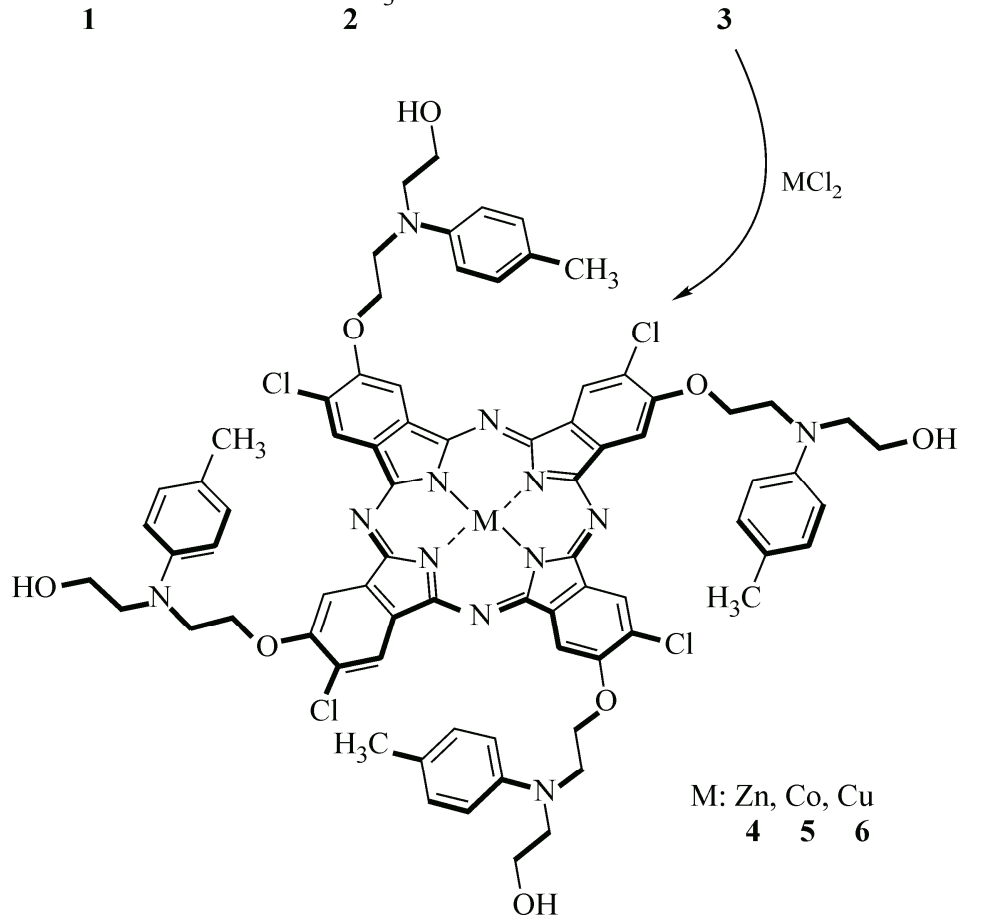

Scheme 1.The route for the synthesis of compound $\mathbf{3}-\mathbf{6}$

The IR spectral data clearly indicated the formation of compound 3 by the appearance of new absorption bands at $3276(\mathrm{OH}), 3085-3015(\mathrm{Ar}-\mathrm{H}), 2923\left(\mathrm{CH}_{3}\right), 2238(\mathrm{CN}), 1617-1575(\mathrm{C}=\mathrm{C})$, $1257(\mathrm{Ar}-\mathrm{O}-\mathrm{CH})$. After conversion of the phthalonitrile derivative 3 into phthalocyanines $\mathbf{4}-\mathbf{6}$, the sharp peak for the $(\mathrm{CN})$ vibrations disappeared [24]. The IR spectrum of $\mathbf{4}$ clearly indicated the formation of compound 4 by the appearance of new absorption bands at $3328(\mathrm{OH}), 3062(\mathrm{Ar}-\mathrm{H})$, $2910-2848\left(\mathrm{CH}_{3}\right), 1601-1517(\mathrm{C}=\mathrm{C}), 1257(\mathrm{Ar}-\mathrm{O}-\mathrm{CH})$. The IR spectra of $\mathbf{5}-\mathbf{6}$ were very similar to the spectrum of $\mathbf{5}$ with slight shifts. The IR spectral data clearly indicated the formation of compounds $5-6$ by the appearance of new absorption bands at 3330-3330 (OH), 3073-3067 $(\mathrm{Ar}-\mathrm{H})$, $2921-2919\left(\mathrm{CH}_{3}\right), 1605-1518(\mathrm{C}=\mathrm{C}), 1257-1261(\mathrm{Ar}-\mathrm{O}-\mathrm{CH})$, respectively, confirming the proposed structures.

Aggregation properties. The investigation of the UV-Vis spectra of phthalocyanines (4-6) confirmed the proposed structures. The aggregation behaviour of all these phthalocyanines have been measured in THF at a concentration range of $10^{-5}-10^{-6} \mathrm{~mol} \cdot \mathrm{L}^{-1}$ and results are presented in Fig. 1 . These phthalocyanines are free from aggregation in this concentration range. The compounds showed 

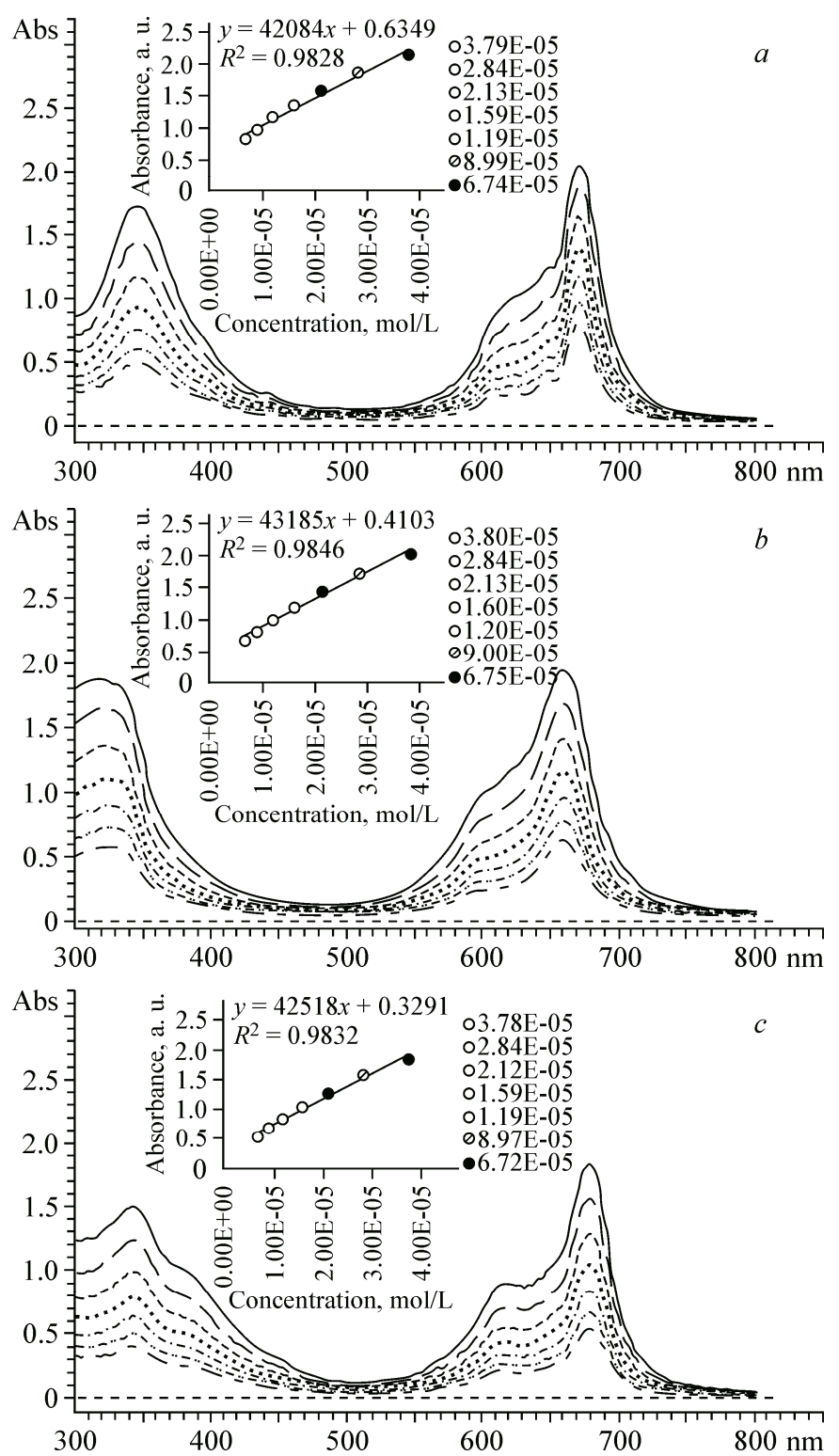

Fig. 1. The aggregation behaviour of phthalocyanine $4(a), 5(b), 6(c)$

characteristic absorptions in the $Q$ band region at $670 \mathrm{~nm}$ for $\mathbf{4}, 660 \mathrm{~nm}$ for $\mathbf{5}$, and $676 \mathrm{~nm}$ for $\mathbf{6}$. Molecular aggregation is a common phenomenon in chemistry of PCS, particularly in water, and gives rise to broadening and blue-shift of their $Q$ band when the chromophores are aligned in a face-to-face manner [25]. This aggregation-free characteristic is extremely important from the viewpoint of its application as photosensitizers in PDT because aggregation phenomena provide an efficient non radiative relaxation pathway and shorten lifetime of excited states in PCS, considerably reducing the photochemical activities of the macrocycles. Also, it is an intriguing subject from a viewpoint of supramolecular chemistry considerably reducing the photochemical activities of the macrocycles [26].

DPPH scavenging activity. The antioxidant activity of the compound $\mathbf{3}$ and its phthalocyanine complexes were measured by means of their hydrogen donating or radical scavenging ability by UVVis spectrophotometer using the stable DPPH. In DPPH scavenging assay, the DMF solutions of the compound $\mathbf{3}$ and its phthalocyanine complexes showed weak activity when compared with standards (Table 1). The antioxidant activities of compounds increased with the increase in concentration $(5 \mathrm{mg} / \mathrm{L}$, $10 \mathrm{mg} / \mathrm{L}, 25 \mathrm{mg} / \mathrm{L}, 50 \mathrm{mg} / \mathrm{L}$, and $100 \mathrm{mg} / \mathrm{L}$ ). Compound 4 exhibited the best activity by $35.2 \%$ at $100 \mathrm{mg} / \mathrm{L}$ concentration. The results were found to be compatible with the literature values [27 ]. 
Antioxidant activity of compounds and standards

\begin{tabular}{|c|c|c|c|c|c|c|}
\hline \multicolumn{7}{|c|}{ DPPH scavenging activity, $\%$} \\
\hline Concentrations & 3 & 4 & 6 & \multicolumn{2}{|c|}{ Ascorbic acid } & Trolox \\
\hline $5 \mathrm{ppm}$ & 2.5 & 5.6 & 3.1 & \multicolumn{2}{|c|}{40.5} & 35.1 \\
\hline $10 \mathrm{ppm}$ & 4.2 & 9.3 & 4.8 & \multicolumn{2}{|c|}{52.8} & 46.5 \\
\hline $25 \mathrm{ppm}$ & 7.6 & 9.1 & 8.9 & \multicolumn{2}{|c|}{95.29} & 91.8 \\
\hline $50 \mathrm{ppm}$ & 14.8 & 29.7 & $16 .^{\circ}$ & \multicolumn{2}{|c|}{97.6} & 95.6 \\
\hline $100 \mathrm{ppm}$ & 21.5 & \multicolumn{2}{|c|}{24.5} & \multicolumn{2}{|c|}{99.1} & 98.7 \\
\hline \multicolumn{7}{|c|}{ Metal chelating activity, $\%$} \\
\hline Concentrations & 3 & 4 & 5 & 6 & \multicolumn{2}{|c|}{ EDTA } \\
\hline $5 \mathrm{ppm}$ & 13.2 & 8.7 & 5.2 & 7.6 & \multicolumn{2}{|c|}{90.3} \\
\hline $10 \mathrm{ppm}$ & 19.5 & 19.8 & 10.3 & 13.4 & 95.3 & \\
\hline $25 \mathrm{ppm}$ & 33.4 & 32.3 & 16.4 & 19.7 & 97.6 & \\
\hline $50 \mathrm{ppm}$ & 48.2 & 41.6 & 21.6 & 24.9 & 100 & \\
\hline $100 \mathrm{ppm}$ & 69.7 & 56.4 & 30.2 & 35.8 & 100 & \\
\hline & & ucing po & er activi & & & \\
\hline Concentrations & 3 & 4 & 5 & 6 & $\alpha$-tocoph & erol \\
\hline $5 \mathrm{ppm}$ & 0.083 & 0.121 & 0.047 & 0.055 & 0.078 & \\
\hline $10 \mathrm{ppm}$ & 0.112 & 0.238 & 0.083 & 0.101 & 0.10 & \\
\hline $25 \mathrm{ppm}$ & 0.198 & 0.374 & 0.131 & 0.146 & 0.221 & \\
\hline $50 \mathrm{ppm}$ & 0.357 & 0.584 & 0.199 & 0.224 & 0.376 & \\
\hline $100 \mathrm{ppm}$ & 0.479 & 0.774 & 0.248 & 0.375 & 0.467 & \\
\hline
\end{tabular}

Metal chelating activity. Ferrozine can quantitatively form complexes with $\mathrm{Fe}^{2+}$. However, by the means of chelating agents, the complex formation is prevented with the result that the red colour of the complex is diminished. With a coexisting chelator, spectrophotometric reduction of colour allows the estimation of the chelating activity. The transition metal ion, $\mathrm{Fe}^{2+}$, possesses the ability to lose single electron by virtue of which it can allow the formation and propagation of many radical reactions, even starting with relatively non-reactive radicals [28]. Only two compounds (3 and 4) displayed above the average activity when compared with other compounds as can be seen in Table 1. EDTA showed precise activity even at low concentrations.

Reducing power activity. In this activity test, the yellow color of the test solution changes to green and blue depending on the reducing power capacity of each compound. The presence of reducers (i.e., antioxidants) trigger the reaction of the $\mathrm{Fe}^{3+} /$ ferricyanide complex to the ferrous form the Perl's Prussion blue after the addition of trichloroacetic acid and ferric chloride, that can be monitored at $700 \mathrm{~nm}$. Compounds 3 and $\mathbf{4}$ exhibited higher activities than $\alpha$-tocopherol which was used as a po-

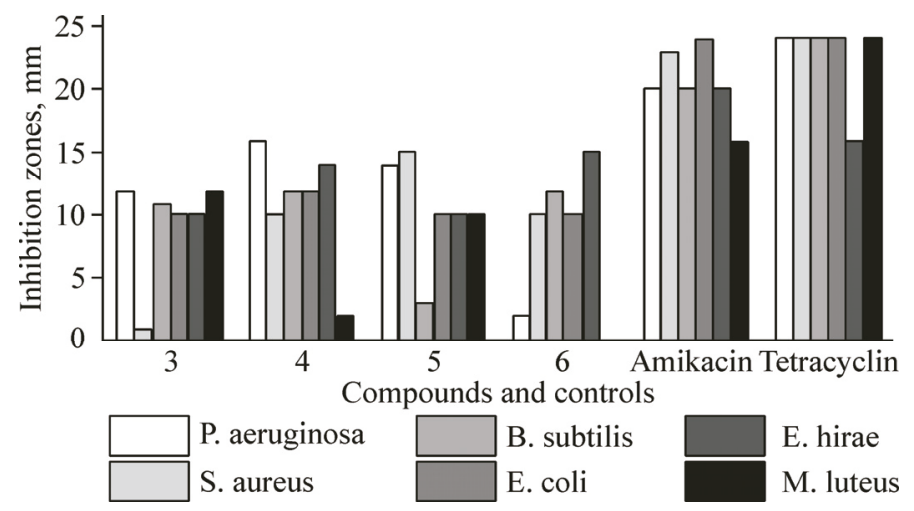
sitive control. The activities were 0.479 for $3,0.774$ for 4 and 0.467 for $\alpha$-tocopherol (Table 1).

Antibacterial activity. Compounds 3-6 were tested for their antibacterial activity as seen at Fig. 2. The potential antibacterial activities of the compounds against Escherichia coli (ATCC 10536),

Fig. 2. Antimicrobial activity of compounds and controls 
Staphylococcus aureus (ATCC 6538), Bacillus subtilis (6051), Enterococcus hirae (ATCC 10541), Micrococcus luteus (ATCC 9341), and Pseudomonas aeruginosa (ATCC 9027) were studied by disc diffusion method. Highest activity was obtained by compound 4 as $16 \mathrm{~mm}$ against to $P$. aeruginosa. The antibiotics that used for control Amicasin and Tetracyclin displayed excellent inhibition activities against all studied microorganisms [29]. These antibacterial activity results were similar to those reported in the literature.

\section{CONCLUSIONS}

The present work describes the synthesis, characterization and aggregation behavior of 4-chloro5-(2-((2-hydroxyethyl)( $p$-tolyl)amino)ethoxy) substituted phthalocyanines and evaluation of their antioxidant and antimicrobial activities. The synthesized phthalocyanine complexes show excellent solubility in a wide range of organic solvents. These compounds do not show aggregation in the concentration range of $10^{-5}-10^{-6} \mathrm{~mol} \cdot \mathrm{L}^{-1}$ that makes them suitable candidates for PDT. In the light of the results obtained from the study, it can be said that compound $\mathbf{4}$ displayed higher activities than the other complexes for both antioxidant and antimicrobial activities. These activities may be further developed by some modifications on the compounds. The antioxidant activities of these compounds were found to be compatible with the literature values $[16,26]$.

This study was supported by the Research Fund of Yüzüncü Y1l University (2013-FBE-D059).

\section{REFERENCES}

1. Leznoff C.C., Lever A.B.P. // Phthalocyanines Properties and Applications. - Vols. 1-4. - Weinheim: VCH, $1989-1996$.

2. McKeown N.B. Phthalocyanines Materials - Synthesis, Structure and Functions. - Cambridge: Cambridge University Press, 1998.

3. Ağırtaş M.S. // Inorg. Chim. Acta. - 2007. - 360. - P. $2499-2502$.

4. Jiang Z., Shao J., Yang T., Wang J., Jia L. // J. Pharm. Biomed. Anal. - 2014. - 87. - P. 98 - 104.

5. Vol'pin M.E., Novodarova G.N., Krainova N.Yu., Lapikova V.P., Aver'yanov A.A. // J. Inorg. Biochem. - 2000. - 8. - P. $285-292$.

6. Ağırtaş M.S., Gümüs S. // Synth. React. Inorg. Met.-Org. Nano-Met. Chem. - 2013. - 43. - P. $624-628$.

7. Altındal A., Öztürk Z.Z., Dabak S., Bekaroğlu Ö. // Sens. Actuators B. - 2001. - 77. - P. 389 - 394.

8. Mathews S.J., Kumar S.C., Giribabu L., Rao S.V. // Mater. Lett. - 2007. - 61. - P. 4426 - 4431.

9. Zhang X.-F., Wang Y., Niu L. // J. Photochem. Photobiol. A. - 2010. - 209. - P. $232-237$.

10. Ji L., Jing L., Lin S., Deng X., Zhu P., Zhang X. // Dyes Pigm. - 2014. - 106. - P. 176 - 181.

11. Zawadzka A., Plóciennik P., Strzelecki J., Korcala A., Arof A.K., Sahraoui B. // Dyes Pigm. - 2014. - 101. - P. $212-220$.

12. Karaoğlan G.K., Gümrükçü G., Koca A., Gül A., Avciata U. // Dyes Pigm. - 2011. - 90. - P. 11 - 20.

13. Mahyari M., Shaabani A. // Appl. Catal. A: General. - 2014. - 469. - P. 524 - 531.

14. Salan Ü., Kobayashi N., Bekaroğlu Ö. // Tetrahedron Lett. - 2009. - 50. - P. 6775 - 6778.

15. Ağırtaş M.S. // Dyes Pigm. - 2007. - 74. - P. 490 - 493.

16. Ağırtaş M.S., Dede E., Gümüşs S., Dündar A., Okumuş V. // Z. Anorg. Allg. Chem. - 2014. - 640, N 10. - P. $1953-1959$.

17. Mandal S., Yadav S., Yadav S., Nema R.K. // J. Chem. Pharm. Res. - 2009. - 1, N 1. - P. 102 - 104.

18. Wöhrle D., Eskes M., Shigehara K., Yamada A. // Synthesis. - 1993. - P. $194-196$.

19. Perrin D.D., Armarego W.L.F. Purification of Laboratory Chemicals. 2nd ed. - Oxford: Pergamon Press, 1980.

20. Blois M.S. // Nature. - 1958. - 181. - P. $1199-1200$.

21. Hsu C., Chen W., Weng Y., Tseng C. // Food Chem. - 2003. - 83. - P. 85 - 92.

22. Yen G.H., Chen Y.H. // J. Agric. Food Chem. - 1995. - 43. - P. $27-32$.

23. Perez C., Pauli M., Bazerque P. // Acta Biol. Med. Exp. - 1990. - 15. - P. 13 - 15.

24. Ağırtaş M.S., Bekaroğlu O. // J. Porphyrins Phthalocyanines. - 2001. - 5. - P. 717 - 720.

25. Isago H., Fujita H., Sugimori T. // J. Inorg. Biochem. - 2012. - 117. - P. 111 - 117.

26. Ağırtaş M.S., Çelebi M., GümüşS., Özdemir S., Okumuş V. // Dyes Pigm. - 2013. - 99. - P. 423 - 431.

27. Taha Z.A., Ajlounia A.M., Momanib W.A., Al-Ghzawia A.A. // Spectrochim. Acta, Part A. - 2011. - 81. - P. $570-577$.

28. Aboul-Enein A.M., El-Baz F.K., El-Baroty G.S, Youssef A.M., Abd El-Baky H.H. // J. Med. Sci. - 2003. - 3. - P. $87-98$.

29. Ilhan S., Baykara H., Oztomsuk A., Okumus V., Levent A., Seyitoglu M., Ozdemir S. // Spectrochim. Acta, Part A. - 2014. - 118. - P. $632-642$. 